\title{
REVIEW
}

\section{A Review of Current Diagnosis, Investigation, and Management of Acute Coronary Syndromes in Elderly Patients}

\author{
Claire McCune $\cdot$ Peter McKavanagh $\cdot$ Ian. B. Menown
}

To view enhanced content go to www.cardiologytherapy-open.com Received: June 28, 2015 / Published online: September 22, 2015

(C) The Author(s) 2015. This article is published with open access at Springerlink.com

\section{ABSTRACT}

The elderly constitute a sizeable proportion of the acute coronary syndrome (ACS) population, and this population is continually increasing in number. Guideline-directed therapy is frequently underutilized in the elderly due to concerns about patient safety. However, studies suggest that this subgroup could benefit from many of the conventional and newer therapies available. This paper reviews current literature in the context of contemporary American and European guidance.

Keywords: ACE inhibitors; Acute coronary syndrome; Angiotensin receptor blockers; Antiplatelet therapy; Elderly; Heart failure; Non ST elevation acute coronary syndrome; Revascularization; Statins; Very elderly

C. McCune $(\varangle) \cdot$ P. McKavanagh · Ian. B. Menown Craigavon Cardiac Centre, Southern Trust, Craigavon, Northern Ireland BT63 5QQ, UK e-mail: clairemccune@doctors.org.uk

\section{INTRODUCTION}

The elderly constitute a significant portion of the acute coronary syndrome (ACS) population, with over 75 year olds representing $27-34 \%$ in European registries [1]. Furthermore, aging patients are an increasing cohort, with over 85 year olds expected to triple by the year 2035 [2]. This changing epidemiology presents new difficulties in diagnostic and management strategies. Cardiovascular medicine is a continually evolving and progressive discipline. However, elderly patients are frequently under-represented in clinical trials, leading to uncertainty among clinicians about the relative efficacy and safety of some treatments in this group and, as a consequence, they are less likely to receive evidence-based therapies [3].

Although at higher baseline risk, this contributes further to the poorer outcomes in elderly patients compared with younger patient groups [4]. This paper aims to review and summarize the latest evidence and guidelines relevant to managing elderly patients, with discussion of current patterns of practice and the obstacles to delivering guideline-directed care. 
This article is based on previously conducted studies and does not involve any new studies of human or animal subjects performed by any of the authors.

\section{CLINICAL CHARACTERISTICS OF ELDERLY PATIENTS WITH ACS}

Mehta et al. analyzed 163,140 hospital admissions of Medicare beneficiaries age $\geq 65$ admitted from 1994 to 1996 and subcategorized these patients by age [5]. Increasing age was associated with a greater incidence of functional limitations, heart failure, prior coronary disease, and renal insufficiency [5]. Conversely, there is less diabetes and fewer male patients in older subgroups [5].

Through analysis of five nationwide Italian registries, De Luca et al. demonstrated the changing characteristics of the elderly cohort ( $>75$ years of age) admitted to coronary care units with an acute myocardial infarction over time from 2001 to 2010 [6]. This showed increased hypertension, renal dysfunction, and previous PCI but reduced history of previous stroke, myocardial infarction, or heart failure compared to earlier cohorts [6].

\section{DIAGNOSIS AND INITIAL TREATMENT}

Recognition of ACS can be difficult in older patient groups. This is due a combination of patient factors with multiple barriers to diagnosis, but also due to inadequacies in service provision. Elderly patient groups are less likely to call emergency services or make their own way to hospital, and patients aged over 65 who do contact emergency services were found to be given a lower priority than patients aged 51-64 years old [7, 8]. The joint
American Colleges of the American Heart Association and American College of Cardiology (AHA/ACC) as well as the European Society of Cardiology (ESC) guidelines state that the initial ECG should be taken within $10 \mathrm{~min}[9,10]$. However, the CRUSADE (Can Rapid Risk Stratification of Unstable Angina Patients Suppress ADverse Outcomes with Early Implementation of the ACC/AHA Guidelines) registry highlighted that elderly patients $(>85)$ on average wait an additional $7 \mathrm{~min}$ before receiving an initial ECG, and women over 85 were shown to wait for an average of $45 \mathrm{~min}[4,11]$.

Diagnosis is further delayed by the atypical presentation of elderly patients as found by the GRACE (Global Registry of Acute Coronary Events) registry [12]. Atypical symptoms included dyspnea in $49 \%$, diaphoresis in $26 \%$, nausea or vomiting in $24 \%$, and syncope in $19 \%$ (Fig. 1) [12]. Other confounders to diagnosis found more frequently in these patients include

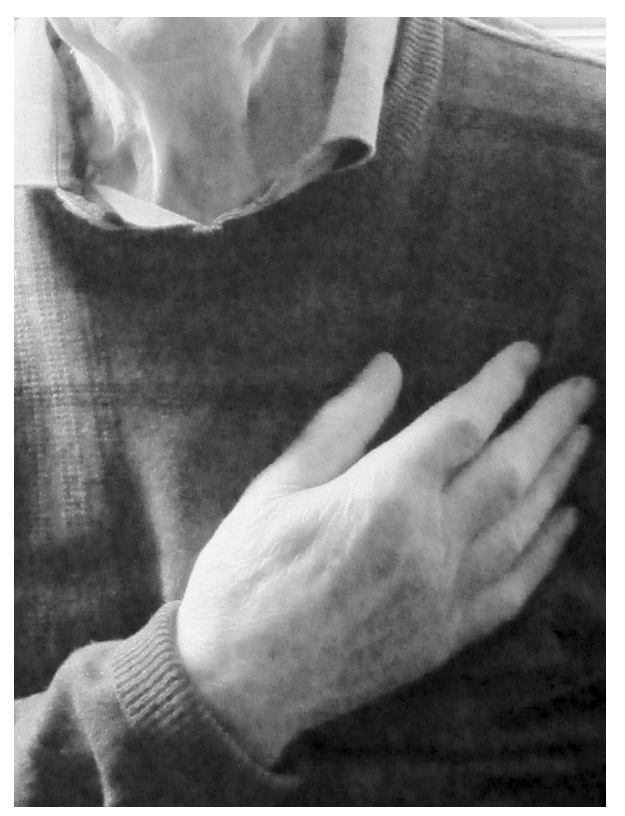

Fig. 1 Elderly patients often present with atypical symptoms other than chest pain 
silent myocardial infarctions, which account for up to $60 \%$ of infarcts in patients over 85 years old, and concurrent illnesses such as pneumonia [4].

Inequalities in care were also found on admission, with elderly patients less likely to be admitted to a cardiology ward or under the care of a consultant cardiologist [13]. This is likely multifactorial, due to factors such as delayed diagnosis, atypical presentation, increased resource requirements, and prolonged length of stay.

Given that elderly patients with ACS have poorer outcomes than their younger counterparts, in part due to the difficulties and delays in diagnosis, a high index of suspicion in the elderly population is therefore advised by European guidelines [10].

\section{ANTIPLATELETS}

Antiplatelet agents as recommended for ACS by AHA/ACC and ESC guidelines are frequently underprescribed in the elderly [14]. Aspirin gained United States Food and Drug Administration approval for use in primary and secondary prevention of cardiovascular disease in 1985. There are no trials designed to assess the effect of aspirin specifically in elderly patients, and elderly patients are underrepresented in other studies despite the increased risk of coronary heart disease and stroke in this group [15]. Analyses of previous trials have shown that patients over the age of 65 have a greater absolute risk reduction and a similar relative risk reduction in vascular end points than younger patient cohorts, and a 22\% lower 30-day mortality (Fig. 2) [4, 14, 16]. Moreover, a similar trend of reduced risk of stroke, myocardial infarction (MI), vascular events, and death was witnessed in the very elderly (>85 years old) $[14,17]$.

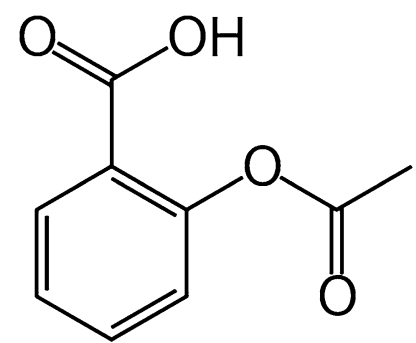

Fig. 2 Medical therapies such as aspirin have an important role in treating many elderly patients

The GRACE registry demonstrated that age is independently linked to an increased bleeding risk in ACS patients. Although many studies have not shown increased bleeding in these groups with pharmacotherapy, this is likely due to patient selection, and concerns remain about bleeding in elderly groups $[14,17,18]$. This is further discussed in a review paper by Patrono et al., who highlight a marked increase in risk of bleeding complications in patients over the age of 70 and especially in patients with a history of gastrointestinal disturbance [15]. The review paper concludes that it is difficult to assess whether the possible benefits of aspirin exceed the risks of upper gastrointestinal bleeding in this age group [15]. However, current AHA/ACC and ESC guidelines recommend the initiation of aspirin in patients with suspected ACS without contraindications and regardless of their age [4, 9, 10]. The ADAPTABLE trial (Aspirin Dosing: A Patient-Centric Trial Assessing Benefits and Long-term Effectiveness) is currently enrolling high-risk patients (previous myocardial infarction or significant coronary disease) to receive lower-dose $(81 \mathrm{mg})$ or higher-dose (325 $\mathrm{mg}$ ) aspirin with the aim to assess efficacy and bleeding risk in patients, comparing older and younger subgroups [19].

COMMIT (Clopidogrel and Metoprolol in Myocardial Infarction Trial) and CURE (Clopidogrel in Unstable Angina to Prevent 
Recurrent Events) (mean age 64.2 \pm 11.3 ) have shown that combining aspirin and clopidogrel is significantly more effective in reducing composite cardiovascular death $(\mathrm{CV})$, non-fatal MI (myocardial infarction), or stroke than aspirin alone $[20,21]$. Conversely, the combination of both drugs offers less benefits to elderly patients than in younger NSTE-ACS (non ST elevation myocardial infarction) patients with similar absolute $(2.0 \%$ vs. $2.2 \%)$ and smaller relative $(13.1 \%$ vs. $28.9 \%)$ risk reductions $[4,21,22]$. An exception is in elderly patients undergoing percutaneous coronary intervention (PCI) with higher risk scores or prior revascularization, where older patients had greater benefit $[4,23]$. CURE showed an increase in the risk of major bleeding with dual therapy vs. aspirin alone (3.7\% vs. $2.7 \%$ placebo; $P=0.001$ ) and a small although nonsignificant $17 \%$ increase in the risk of life-threatening bleeding $(2.1 \%$ vs. $1.8 \%$, $P=0.13$ ) [21]. Some authors suggest the routine use of proton pump inhibitors (PPI), which have been shown to decrease the higher incidence of gastrointestinal bleeding associated with antiplatelets in older patients [24].

The recent introduction of more potent P2Y12 antiplatelet agents has raised more questions in treating the elderly with NSTE-ACS. Ticagrelor is increasingly used in the general population, but guidelines provide limited input with regards to prescription in elderly patients. PLATO (PLATelet inhibition and patient Outcomes) showed ticagrelor as compared with clopidogrel in patients with acute coronary syndromes (also receiving aspirin) was associated with significantly reduced rates of cardiovascular death, myocardial infarction, or stroke without an increase in overall major bleeding, although also with an increase in non-CABG-related
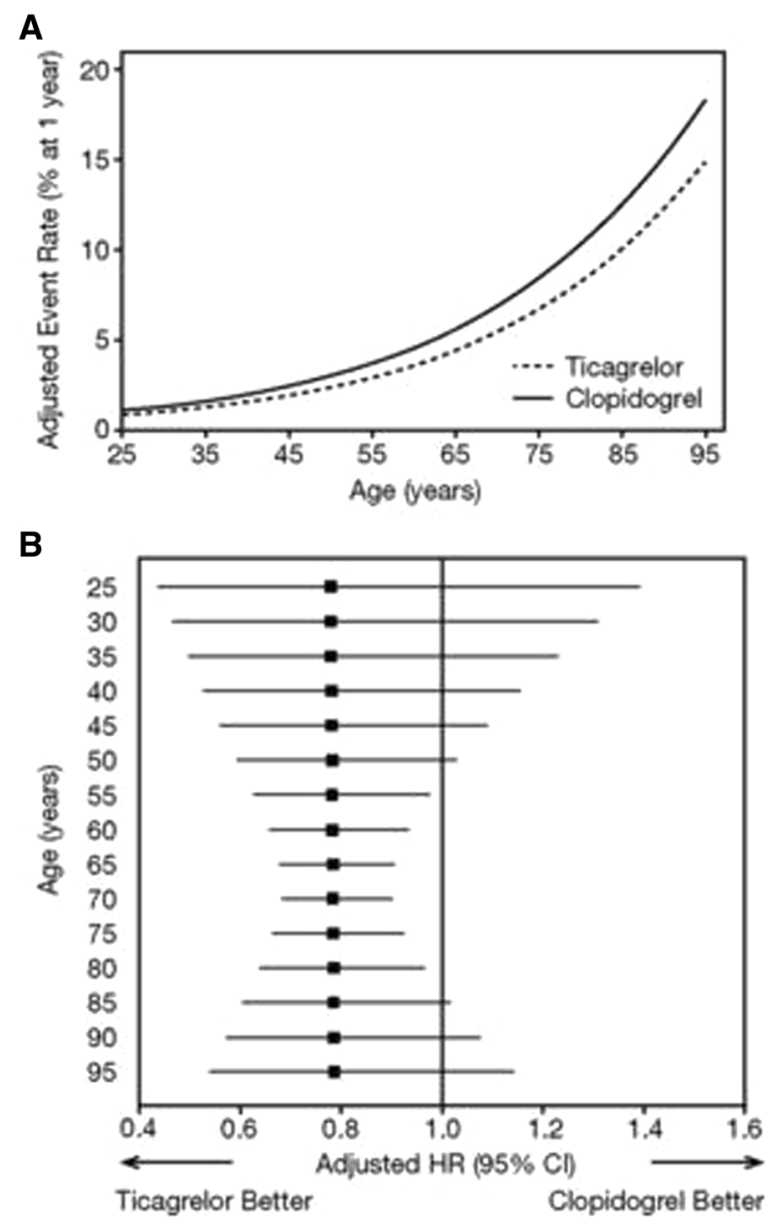

Fig. 3 All-cause mortality according to age. a Estimated event rate at 12 months, ticagrelor vs clopidogrel. b Treatment effect by patient age. $H R$ hazard ratio, $C I$ confidence interval. Reproduced with permission from [29]

bleeding (Fig. 3) [25]. Notably, this trial used PLATO definitions of bleeding, with higher non-CABG major bleeding rates seen when using TIMI definitions [26]. Additionally, there was a significant excess of fatal intracranial bleeding in the ticagrelor group (11 [0.1\%] vs. 1 [0.01\%], $P=0.02$ ) and excess stroke with ticagrelor in the STEMI (ST elevation myocardial infarction) population $1.7 \%$ vs. $1.0 \%$ (hazard ratio, 1.63; 95\% CI, 1.07 to $2.48 ; P=0.02)[26,27]$. Lindholm et al. found no benefit for patients $>65$ undergoing 
revascularization (interaction $P<0.01$ vs. patients $<65$ years) [28].

In a PLATO substudy of elderly patients ( $>75$ years), while absolute incidences of vascular events and bleeding events were higher in the elderly, there was no significant heterogeneity in the benefit of ticagrelor over clopidogrel between patients $\geq 75$ years $(n=2878) \quad$ vs. $\quad<75$ years $\quad(n=15744) \quad$ with respect to reduction in composite cardiovascular death, myocardial infarction, or stroke (interaction $P=0.56$ ); myocardial infarction (interaction $P=0.33$ ); cardiovascular death (interaction $P=0.47$ ); definite stent thrombosis (interaction $P=0.81$ ); or all-cause mortality (interaction $P=0.76) \quad$ [29]. Similarly, there was no significant heterogeneity in the small excess of PLATO-defined non-CABG major bleeding with ticagrelor vs. clopidogrel between patients $\geq 75$ years vs. $<75$ years (interaction $P=0.98$ ) (Fig. 4) [29]. A reduced dose of $60 \mathrm{mg}$ twice daily as an alternative to $90 \mathrm{mg}$ twice daily may be safer in the elderly as suggested by the PEGASUS-TIMI 54 (Prevention of Cardiovascular Events in Patients With Prior Heart Attack Using Ticagrelor Compared to Placebo on a Background of Aspirin-Thrombolysis in Myocardial Infarction 54) trial [30]. Although dyspnea and ventricular pauses were more frequent overall with ticagrelor, there was no finding of an age-related interaction [29].

TRITON-TIMI 38 (Trial to Assess Improvement in Therapeutic Outcomes by Optimizing Platelet Inhibition with Prasugrel-Thrombolysis In Myocardial Infarction 38) compared prasugrel with clopidogrel in patients with ACS who were scheduled to have PCI. Patients $\geq 75$ years old had only a small (6\%), nonsignificant reduction
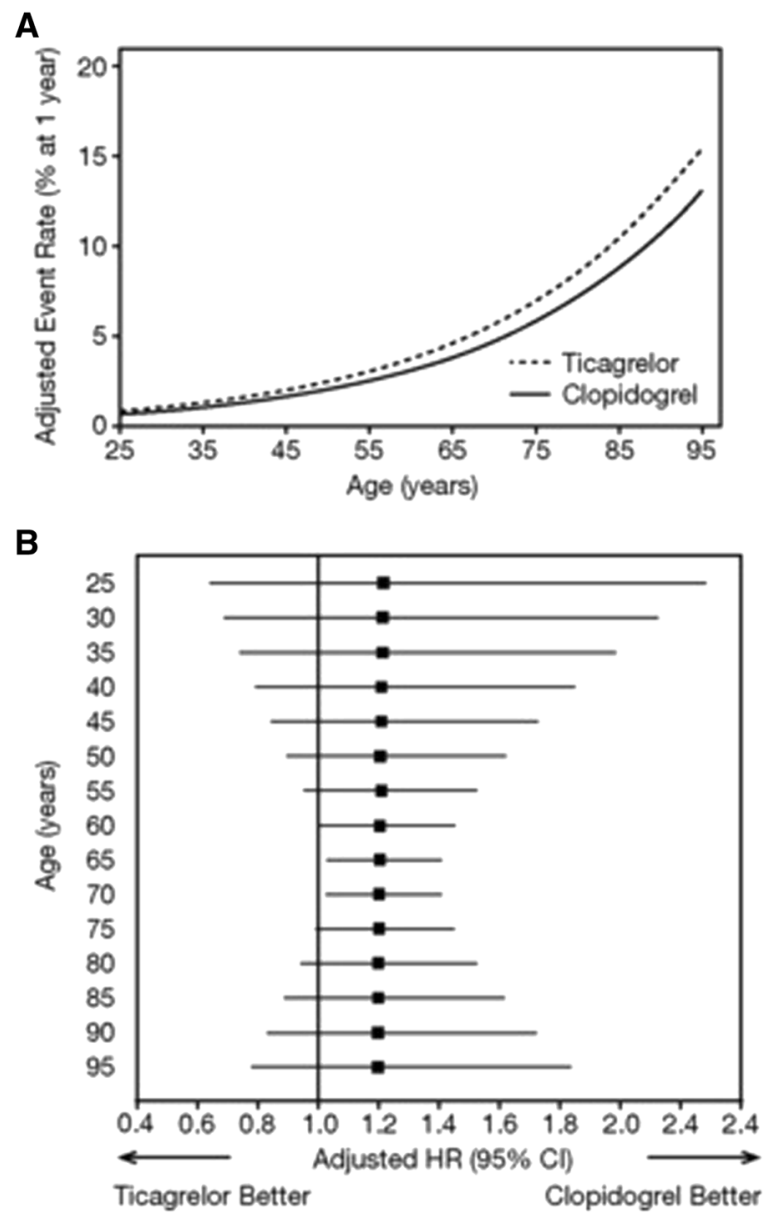

Fig. 4 Overall non-coronary artery bypass graft-related bleeding according to age. a Estimated event rate at 12 months, ticagrelor vs clopidogrel. b Treatment effect by age. $H R$ hazard ratio, $C I$ confidence interval. Reproduced with permission from [29]

in the primary efficacy endpoint offset by an excess of TIMI major bleeding, leading to a nonsignificant net clinical benefit (hazard ratio, $0.99 ; 95 \% \mathrm{CI}, 0.81$ to $1.21 ; P=0.92)[31,32]$. The excess of bleeding with prasugrel showed a similar relative but greater absolute increase in the subgroup $\geq 75$ years and in the subgroup $<60 \mathrm{~kg}$ (common in the elderly) [31, 33]. Furthermore, those with a history of stroke or transient ischemic attack (common in elderly groups) demonstrated net harm due to non-CABG-related nonfatal TIMI major 
bleeding [31]. Currently, the use of prasugrel in patients $\geq 75$ years of age is generally not recommended, and if undertaken (with caution after a careful individual benefit/risk evaluation by the prescribing physician), a lower maintenance dose of $5 \mathrm{mg}$ should be used; the 10-mg maintenance dose is not recommended [10]. History of stroke or transient ischemic attack is a contraindication [34]. Research to investigate the use of a reduced dose of prasugrel includes the secondary analysis of TRILOGY ACS (TaRgeted platelet Inhibition to cLarify the Optimal strateGy to medicallY manage Acute Coronary Syndromes) and the ongoing Elderly ACS II trial (ClinicalTrials.gov IDNCT01777503) [35].

\section{ANTICOAGULATION}

Multiple studies have shown that anticoagulation with unfractionated heparin (UFH) or low molecular weight heparin (LMWH) can reduce death or MI in NSTE-ACS [4, 36-43]. However, in elderly patients, there are very limited data on the efficacy and safety compared to younger patient subgroups, as many studies fail to report patient age [43]. Older age may be linked to higher blood levels of heparin and activated partial thomboplastin time, as well as higher anti-Xa levels with renally excreted LMWH [4, 44]. LMWH has been found to have a more predictable dose response than UFH, but still may benefit from dose adjustment according to age, body weight, and renal function (the latter two may decline with age) [45].

The SYNERGY (Superior Yield of the New strategy of Enoxaparin, Revascularization and GlYcoprotein IIb/IIIa inhibitors) trial demonstrated a nonsignificant trend of increased TIMI major and GUSTO (Global Utilization of Streptokinase and Tissue
Plasminogen Activator for Occluded Coronary Arteries) severe bleeding with enoxaparin compared with UFH, but similar rates of death or myocardial infarction in elderly patients [46]. As a consequence, ESC guidelines suggest reducing the dose adjustment of $1 \mathrm{mg} / \mathrm{kg}$ once daily in patients over 75 years old with monitoring of anti-Xa levels [10]. In comparison, the AHA/ACC recommend $1 \mathrm{mg} /$ $\mathrm{kg}$ twice daily with alteration based on individual patient characteristics, including creatinine clearance [9]. The direct thrombin inhibitor fondaparinux, which achieves a relatively low level of anticoagulation (50\% of the anti-Xa level of enoxaparin at standard doses) was found to have a lower bleeding risk but a similar efficacy to enoxaparin in the OASIS 5 (Organization for the Assessment of Strategies for Ischemic Syndromes 5) trial, even with moderate renal impairment [47]. However, given the relatively low level of anticoagulation, top up with unfractionated heparin is required to reduce the risk of catheter thrombosis if the patient undergoes PCI [46].

Anticoagulation may also be required for additional reasons such as atrial fibrillation. Atrial fibrillation doubles in prevalence with each decade of age, reaching almost 9\% at 80-89 years old [48]. Unsurprisingly, many patients that present with NSTE-ACS have concurrent atrial fibrillation and therefore warrant consideration for triple therapy (vitamin $\mathrm{K}$ antagonist, aspirin, and a P2Y12 receptor inhibitor); however, this is associated with a three- to fourfold increase in major bleeding complications [10]. It has been demonstrated that oral anticoagulation increases the risk of intracranial hemorrhage with increasing age [49]. The complication is of particular importance due to its higher mortality rate [49]. The risk is further increased in patients with hypertension, 
cerebrovascular disease, and with a higher dosage of anticoagulant [49].

In patients with atrial fibrillation and a moderate to high risk of stroke, American and European guidelines advocate bleeding risk assessment, consideration of stent type (bare metal vs. drug-eluting stent), and limitation of triple therapy duration accordingly $[9,10]$. The HAS-BLED (Hypertension, Abnormal Renal/ Liver Function, Stroke, Bleeding History or Predisposition, Labile INR, Elderly, Drugs/ Alcohol Concomitantly) score may help in such decision-making and acknowledges the increased bleeding risk with age [9]. Although some guidelines advocate the use of a narrower therapeutic range (2.0-2.5), this has not been investigated through prospective studies [9].

\section{OTHER THERAPIES}

Adjunctive therapies are often underprescribed in the elderly, including patients with no clear contraindication. This is likely multifactorial, due to concerns about polypharmacy, drug interactions, and a lack of information on the risk benefit of medications in this population.

High-intensity statin therapy is recommended for ACS patients who are not contraindicated by both the ESC and AHA/ACC guidelines $[4,50]$. The PROVE IT (Pravastatin or Atorvastatin Evaluation and Infection Therapy) study showed a $16 \%$ reduction in death, MI, stroke, late revascularization or readmission for unstable angina with high-dose atorvastatin compared to pravastatin, with this effect extending to older age groups [51]. PROSPER (PROspective Study of Pravastatin in the Elderly at Risk) showed a $15 \%$ relative and $2.1 \%$ absolute risk reduction in death or $\mathrm{MI}$ in patients over 70 with high-risk features [52]. The CARE (Cholesterol And Recurrent Events) and LIPID
(Long-term Intervention with Pravastatin in Ischemic Disease) trials also showed a benefit of statin use in patients aged $65-75$ with a reduced rate of CAD deaths $[53,54]$. In the very elderly (octogenarian) age group, the value of lipid-lowering therapy can be more contentious since randomized data are relatively scarce and analysis may be confounded by an observational J-shaped association between cholesterol levels and all-cause mortality [55]. Nevertheless, the latest NICE guidance recommends consideration of statin therapy in those $>85$ years to reduce the rate of nonfatal myocardial infarction unless treatment is deemed inappropriate due to comorbidity, polypharmacy, general frailty, or life expectancy [56]. The effect of angiotensin-converting-enzyme (ACE) inhibitors has also been studied in older patient groups. GISSI 3 (Gruppo Italiano per lo Studio della Sopravvivenza nell'infarto Miocardico) was a large Italian randomized trial investigating the use of ACE inhibitors in acute MI patients with preserved left ventricular function, and included a large proportion (27\%) of elderly patients [57]. This showed that ACE inhibitors post myocardial infarction reduce combined death, heart failure, and left ventricular systolic function at 6 months [57].

The subsequent studies SAVE (Salvage and Ventricular Enlargement) and AIRE (Acute Infarction Ramipril Efficacy) have demonstrated reduced long-term mortality in elderly patients over 65 years of age after acute myocardial infarction with reduced left ventricular function [58, 59]. Krumholz et al. studied the effect of ACE inhibitors in 14,129 post-MI patients aged 65 and older, and found that patients who used ACE inhibitors had a significantly reduced 1-year mortality, with this benefit also significant within the $>80$-year-old subgroup [60]. 
Angiotensin receptor blockers have also been found to benefit outcome post myocardial infarction in the elderly, albeit with an increased incidence of side effects compared with younger patients [61-63].

Aldosterone antagonists can be more difficult to use in elderly patients, particularly in the setting of reduced renal function. While EPHESUS (Eplerenone Post-acute myocardial infarction Heart failure Efficacy and SUrvival Study) did demonstrate an efficacy benefit in elderly patients with left ventricular dysfunction post MI, there was a samller benefit of treatment than seen in younger patients but a higher risk of side effects, including hyperkalemia $[61,64]$.

Conversely, beta blockade has been shown to have a similar beneficial effect in both younger and elderly subgroups, with decreased mortality and re-infarction post MI [61, 65-67]. GUSTO-I and COMMIT showed that patients receiving early intravenous beta blockade had a higher risk of an adverse outcome than oral beta-blocker groups, particularly in elderly STEMI patients who are at risk of hemodynamic instability and heart failure [68, 69].

The benefits of current guideline-directed medical therapies also extend to nonpharmacological methods.

Cardiac rehabilitation has been shown to improve exercise capacity, diabetic glucose control, autonomic function, behavioral characteristics, quality of life, future hospitalization costs, and major cardiovascular morbidity and mortality. Despite having comparable benefit in both elderly patients and younger groups, few are still referred [70]. This was further demonstrated by Suaya et al., who found that cardiac rehabilitation was used in only $13.9 \%$ of elderly patients (defined as $>65$ ) who survived 30 days after an acute myocardial infarction and $31 \%$ of patients after bypass surgery [71]. Notably, the most powerful predictor of patient participation is physician referral and encouragement [72]. Patients who decline rehabilitation should be encouraged to exercise for at least $30 \mathrm{~min}$ on most days and preferably for 45 min 4-5 times a week [72].

Several specific considerations must be made for elderly patients when considering cardiac rehabilitation. It is important to assess each individual's physical capability and consider the variations in physiology patients experience with age; for example, elderly patients could benefit from a longer warm-up time [73]. Moreover, an appropriate cooling-down period is particularly important to prevent hypotension (secondary to a delayed baroreceptor response post exercise) [73].

\section{REVASCULARIZATION}

Due to a growing elderly population with a high prevalence of coronary disease, the question of whether to revascularize and the strategy of choice is becoming increasingly relevant. At present, research is limited regarding outcomes of elderly patients receiving revascularization therapies, as many major trials fail to enroll elderly subgroups $[4,61]$.

The merits of revascularization have been shown in elderly patients with symptomatic stable ischemic heart disease. TIME (Trial of Invasive versus Medical therapy in Elderly patients with chronic symptomatic coronary artery disease) randomized 305 patients aged 75 and above with chronic angina (despite being treated with two antianginal medications) to revascularization vs. medical therapy only [74]. Patients in the revascularization group showed symptom relief and improved quality of life, with a reduction in the composite of death/MI/ 
readmission with ACS at 6 months (49\% medical vs. $19 \%$ revascularization $(P<0.0001)$ [70]. The large although observational APPROACH (Alberta Provincial Project for Outcome Assessment in Coronary Heart Disease) registry compared 4-year outcomes among 21,573 patients undergoing diagnostic cardiac catheterization. Those 70-79 years of age and, particularly, those $\geq 80$ years of age showed greater adjusted reductions in death with revascularization compared with medical therapy than in those $<70$ years of age [75].

Furthermore, the benefits of revascularization may extend into elderly subgroups with NSTE-ACS. FRISC II (Fragmin and fast Revascularization during InStability in Coronary artery disease) was a randomized controlled trial comparing initial conservative treatment to an invasive strategy (within 7 days from admission) in patients with NSTE-ACS [76]. At 6 months, the invasive strategy was associated with a lower rate of death or MI (in patients who were troponin positive or with ST changes); the benefit being sustained out to 5 years [76]. While FRISC II excluded patients $>75$ years old, those aged $65-75$ years showed a greater absolute reduction in composite death or MI with an invasive treatment strategy compared with patients $<65$ years of age [76].

The TACTICS-TIMI 18 (Treat Angina with Aggrastat and Determine Cost of Therapy with an Invasive or Conservative Strategy) trial is frequently quoted in clinical guidelines, as it was one of the first to establish that patients presenting with non ST elevation ACS assigned to an early invasive strategy had a reduction in incidence of the composite of death, MI, or readmission with ACS compared with those treated by a conservative strategy [77]. Less well known is that the significant reduction in death or MI achieved with an invasive strategy was confined to those $\geq 65$ years of age $(8.8 \%$ vs.
$13.6 \% ; P=0.018)$, and no significant difference was seen in those $<65$ years of age $(6.1 \%$ vs. $6.5 \% ; P>0.2)$ [78]. This benefit was even greater in those $>75$ years $(10.8 \%$ vs. $21.6 \% ; P=0.016)$, albeit with higher major bleeding rates $(16.6 \%$ vs. $6.5 \% ; P=0.009$ ), likely exacerbated by the protocol-mandated use of glycoprotein IIb/IIIa inhibitor in both arms [78]. Savonitto et al. investigated 313 patients aged 75 years and over, randomly allocating them to an early aggressive strategy (angiography with revascularization if indicated within $72 \mathrm{~h}$ ) vs. an initially conservative strategy (angiography and revascularization only for patients with recurrent ischemia) [79]. The primary endpoint included death, myocardial infarction, disabling stroke, repeat hospital stay for cardiovascular cause, or severe bleeding within 1 year [79]. The primary endpoint occurred in $27.9 \%$ (43) of patients undergoing an early aggressive strategy compared to $34.6 \%$ (55) of the initial conservative group (hazard ratio, 0.80; 95\% CI, 0.53-1.19; $P=0.26$ ) [79]. There was no significant difference in the rates of mortality, myocardial infarction, and readmission between each group [79]. Patients with normal troponin levels on admission had no benefit from an early aggressive approach, but those with elevated troponin had a significant $57 \%$ reduction in the primary endpoint rate ( $P$ for interaction: 0.0375) [79].

\section{Choice of Revascularization Strategy}

Factors such as morbidity, mortality, and complications should be considered when deciding upon the most appropriate revascularization strategy $[9,10]$. Initial studies of PCI in elderly subgroups demonstrated an increased risk of complications; however, as technology and techniques have improved over time, this risk has decreased, with high numbers 


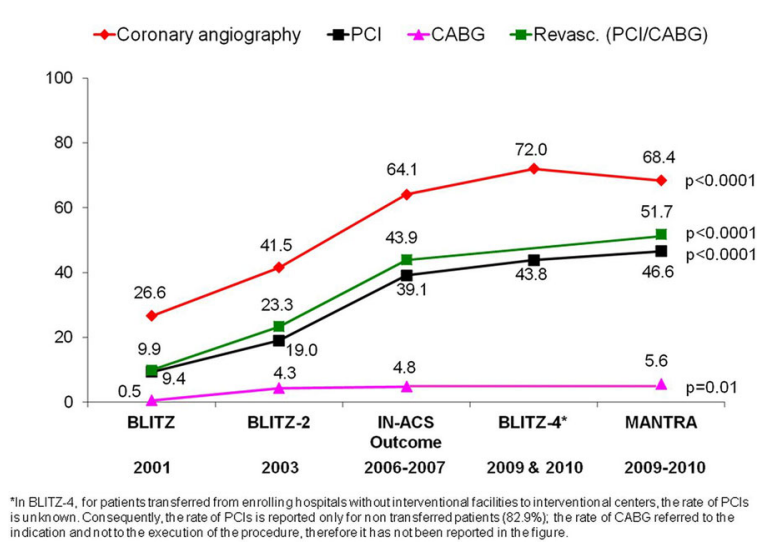

Fig. 5 Choice of revascularization strategy in elderly patients over the past decade from 5 nationwide Italian registries. Reproduced from [6]

of elderly patients undergoing PCI (Fig. 5) [6]. Furthermore, elderly PCI is increasingly being performed in patients with multiple comorbidities without a significant change in risk, as demonstrated in the Scottish Coronary Revascularization Register [80].

The choice of strategy can be more complex when considering patients with multivessel and left mainstem disease. This finding is more prevalent in elderly populations, who also tend to have higher levels of comorbidity. CABG often achieves complete revascularization but may entail prolonged postoperative recovery in elderly patients, whereas PCI may enable same or next-day discharge, early recovery, and potentially a quicker improvement in quality of life.

The mortality benefits of revascularization strategies have been investigated in multiple observational studies. Weintraub et al. compared CABG versus PCI in patients $>65$ years of age with multivessel disease, and found a similar mortality at 1 year but improved survival, reduced stroke, and MI at 4 years for CABG patients [81].

Dacey et al. undertook a review of 1693 octogenarians (80-89 years) undergoing revascularization for two- or three-vessel disease between 1992 and 2001. CABG (predominantly on pump) was associated with higher in-hospital and 6-month mortality compared to PCI but improved survival from 6 months to 8 years [82].

In a small observational study, Sheridan et al. found that, even in the very elderly (aged 85 and over), while PCI was associated with improved early survival, CABG was associated with a small improvement in survival by 36 months (66\% vs. 63\%, $P<0.05)$, although it was noted that the CABG patients were highly selected: they were without congestive heart failure, pulmonary disease, or peripheral vascular disease [83]. Appropriate patient selection for CABG is very important, particularly in the elderly. Alexander et al. showed that 30-day mortality post-CABG was markedly higher in elderly patients overall ( $8.1 \%$ vs. $3 \%$ in younger patients), whereas elderly patients without significant comorbidity had a 30-day mortality of 4\%-approaching that of their younger counterparts [84].

In an analysis of ten trials, Hlatky et al. suggested that CABG confers a mortality benefit specifically in diabetic patients $>65$ years in comparison to PCI [85]. A systematic review of 66 studies (65 observational) concluded that revascularization could be performed in octogenarians with acceptable short- and long-term outcomes, but definite conclusions could not be drawn regarding survival benefit given the paucity of current data [85].

Although these studies suggest that elderly patients free from comorbidity have postoperative outcomes approaching those of a younger age group, a more robust method of identifying these patients is required. This could allow a better understanding of the risks and benefits for both the patient and the medical team. Additionally, the risk of postoperative 
complications may take precedence over mortality risk. Alexander et al. showed that octogenarians have an increased risk of neurological and renal complications (twice the rate of younger patients) [84]. On reviewing 88,154 patients after CABG $(43,369$ aged $65-79,8170$ patients over 80 years), Bardakci et al. concluded that although early outcomes of octogenarians are acceptable, there are "strikingly lower discharge to home rates," and that long-term quality of life data in this age group are required [86].

These studies have suggested several potential benefits of revascularization. However, the majority of evidence is observational and based on selected elderly patients. Evidence for CABG in multivessel disease has so far demonstrated increased long-term freedom from cardiac events and improvement in symptoms. Nevertheless, with increased morbidity and mortality in the postoperative period, a longer recuperation time, and increased risk of long-term cognitive impairment ( 1 in 5 patients), surgical revascularization may not be an acceptable risk to the individual patient.

Current AHA/ACC guidelines state it is reasonable to choose CABG over PCI in NSTE-ACS patients, particularly in diabetics or in those with complex triple vessel disease, to reduce cardiovascular disease events and readmission and to improve survival (IIa level B) [9]. ESC guidelines state that the elderly should be considered for an early invasive strategy with the option of revascularization after carefully weighing up the risks and benefits (IIa level B) [11].

\section{STEMI}

The disadvantages incurred by the elderly with NSTE-ACS are paralleled in elderly STEMI patients by a higher likelihood of delayed or atypical presentation [77]. In addition, many elderly patients have pre-existing LBBB which may confound patient diagnosis [77]. Multiple trials regarding oral pharmacotherapy in acute myocardial infarction do not differentiate between STEMI and NSTEMI; this is therefore addressed separately (also refer to Table 1).

Due to concerns regarding increased hemorrhagic risk, multiple thrombolysis trials excluded elderly patients; however, the survival benefit from reperfusion in STEMI patients found in GUSTO I, ISIS-2, and GISSI studies extended to elderly subgroups [87-90]. Berger et al. showed a benefit in 1-year mortality (but not 30-day survival) in selected thrombolysis patients [91]. In clinical practice, thrombolysis has often been underutilized in the elderly, likely due to concerns about risk of intracranial hemorrhage and nonhemorrhagic stroke (especially in the very elderly), despite the greater absolute benefit in this population [77, 92]. Furthermore, the adjunctive administration of pre-hospital enoxaparin at a standard dose was associated with an increased rate of intracranial hemorrhage in elderly patients in the ASSENT-3 (ASsessment of the Safety and Efficacy of a New Thrombolytic) PLUS trial [93]. The Enoxaparin and Thrombolysis Reperfusion for Acute Myocardial Infarction Treatment (ExTRACT)-Thrombolysis In Myocardial Infarction (TIMI) 25 trial compared the use of adjunctive enoxaparin to unfractionated heparin in patients receiving thrombolysis [94]. An alternative regimen of enoxaparin administration was devised for patients aged $>75$, and involved omitting the initial loading dose and reducing subsequent subcutaneous doses to $0.75 \mathrm{mg} / \mathrm{kg}$ every $12 \mathrm{~h}$ (with a maximum dose of $75 \mathrm{mg}$ ) [94]. This trial showed a reduction in the primary endpoint (composite death from any cause or nonfatal 
Table 1 Summarizing current evidence and guidelines for elderly ACS patients

\begin{tabular}{|c|c|c|}
\hline & Current Evidence, Risks and Benefits & Guideline \\
\hline 竞 & $\begin{array}{l}\text { ISIS-2 } R C T \downarrow \text { risk of vascular events, CVA, non fatal MI and CV death in general population[90] } \\
\text { GRACE registry- Bleeding risk } \uparrow \text { with age[18] } \\
\text { Krumholz et al, retrospective observational (aged }>65 \text { years) MI } \\
\text { No significant excess bleeding (undefined) } 139 / 6140(2.3 \%) \text { aspirin vs. } 122 / 3878(3.2 \%) \\
22 \% \downarrow 30 \text { day mortality if given within } 48 \text { hours } \\
14 \% \text { aspirin (860/6140) vs. } 24.3 \% \text { ( } 943 / 3878) \text { OR, } 0.78 ; 95 \% \text { CI } 0.70 \text { to } 0.89, \mathrm{P}=<0.0001[14] \\
\text { Ongoing ADAPTABLE trial- is lower loading dose }(81 \mathrm{mg}) \text { as efficacious?[19] }\end{array}$ & $\begin{array}{l}\text { Treatment decisions in the } \\
\text { elderly ( }>75 \text { years) should be } \\
\text { made in the context of } \\
\text { estimated life expectancy, } \\
\text { co-morbidities, quality of } \\
\text { life, and patient wishes and } \\
\text { preferences -ESC[10] }\end{array}$ \\
\hline 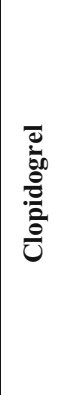 & $\begin{array}{l}\text { CURE (mean age } 64.2+/-11.3)(19 \% \text { age }>75) \text { RCT double blind NSTE-ACS } \\
\leftrightarrow \text { AR, } \downarrow \text { RR reductions for aspirin/clopidogrel combination not having PCI }[21] \\
\uparrow \text { major bleeding } 3.7 \% \text { clopidogrel vs. } 2.7 \% \mathrm{P}=0.001 \text { RR:1.38[21] } \\
>65 \text { years subgroup } \mathrm{CV} \text { death or MI RR } 0.79 \text { clopidogrel vs. placebo } 95 \% \text { CI } 0.57-1.08[22] \\
\text { All age groups- death from CV cause, nonfatal MI or stroke } 9.3 \% \text { vs. } 11.4 \% \mathrm{P}<0.001 \text { RR:0.80, } \\
\text { CI:0.72-0.90[22] } \\
\text { Benefit in patients receiving PCI with higher TIMI score or prior revascularization[23] } \\
\text { COMMIT }(26 \% \text { age }>75) \text { RCT double blind STEMI } \\
\downarrow \text { death, reinfarction or CVA } 9.2 \% \text { vs. } 10.1 \% \text { placebo } \mathrm{P}=0.002 \\
\text { No significant excess bleeding in patients aged }>70[20]\end{array}$ & $\begin{array}{l}\text { Thrombolysis: } \\
\text { loading dose of clopidogrel } \\
300 \mathrm{mg} \text { orally if aged } \leq \mathbf{7 5} \\
\text { years }[\mathbf{9 5}]\end{array}$ \\
\hline 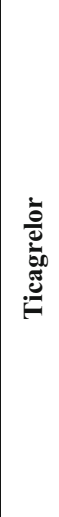 & $\begin{array}{l}\text { PLATO RCT ticagrelor vs. clopidogrel NSTE-ACS ( } 16 \% \text { age }>75 \text { ) } \\
\text { Significantly } \downarrow \text { primary outcome composite vascular death, MI or CVA } 9.8 \% \text { clopidogrel vs. } 11.7 \% \\
\text { (HR, } 0.84 ; \text { CI: } 0.77-0.92, \mathrm{P}<0.001)[25] \\
\text { No increased benefit in patients }>65 \text { years old undergoing revascularization (interaction } \mathrm{p}<0.01 \text { vs. } \\
\text { patients }<65 \text { years) }[28] \\
\text { PLATO } \geq 75 \text { subgroup analysis } 2878 \text { patients } \\
\text { Primary outcome } 17.2 \% \text { vs. } 18.3 \% \text { in clopidogrel group (HR, } 0.89 ; 95 \% \text { CI } 0.74-1.08) \\
\leftrightarrow \text { benefit for age } \geq 75 \text { vs. }<75 \text { ( } \mathrm{P}=0.56 \text { for interaction) } \\
\leftrightarrow \text { of definite stent thrombosis and all cause mortality[ } 29] \\
\uparrow \text { numbers of fatal intracranial bleeding ( } 11(0.1 \%) \text { vs. } 1(0.01 \%), \mathrm{P}=0.02) \\
\text { Small excess non-CABG-related bleeding (PLATO defined) }(4.5 \% \text { vs. } 3.8 \%, \mathrm{P}=0.03) \\
\text { Dyspnea and ventricular pauses increased (not age dependent) }[25] \\
\text { PEGASUS is currently investigating use of reduced dose ticagrelor }[30]\end{array}$ & \\
\hline
\end{tabular}


Table 1 continued

\begin{tabular}{|c|c|c|}
\hline & Current Evidence, Risks and Benefits & Guideline \\
\hline $\begin{array}{l}\bar{D} \\
\bar{D} \\
\bar{E} \\
\bar{E} \\
\mathbb{E}\end{array}$ & $\begin{array}{l}\text { TRITON-TIMI } 38 \text { RCT prasugrel vs. clopidogrel } \\
\text { Subgroup age } \geq 75 \text {, bodyweight }<6 \text { k k or history of stroke or TIA } \\
\text { Non significant reduction in the primary efficacy endpoint (death from CV cause, non fatal MI or non } \\
\text { fatal stroke) } 16.1 \% \text { vs. } 16 \% \text { clopidogrel (HR, } 1.02(0.84-1.24) \mathrm{P}=0.83)[31] \\
\text { Similar relative but greater absolute } \uparrow \text { in bleeding } \\
\text { Non CABG related TIMI major bleeding } 4.3 \% \text { vs. } 3.3 \% \text { clopidogrel (HR, } 1.42(0.93-2.15), \mathrm{P}=0.1) \\
\text { Spontaneous fatal hemorrhage } 9 \text { vs. } 0 \text { with clopidogrel } \\
\text { Death from any cause, non fatal MI, non fatal CVA or non CABG related non fatal TIMI major } \\
\text { bleeding } 20.2 \% \text { vs. } 19 \% \text { (HR } 1.07(0.90-1.28), \mathrm{P}=0.43) \\
\text { No significant net clinical benefit (HR, } 0.99 ; 95 \% \text { CI } 0.81 \text { to } 1.21, \mathrm{P}=0.92)[31-32] \\
\text { Ongoing research with secondary analysis of TRILOGY ACS and Elderly ACS II trials. }\end{array}$ & $\begin{array}{l}\text { Not recommended in } \geq 75 \\
\text { year olds (or }<60 \mathrm{~kg} \text { or prior } \\
\text { CVA/TIA) in both European } \\
\text { and American guidelines }[50, \\
95] \\
\text { If used a similar loading dose } \\
\text { but a reduced maintenance } \\
\text { dose of } 5 \mathrm{mg} \text { should be } \\
\text { considered[95] }\end{array}$ \\
\hline 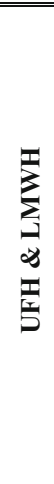 & $\begin{array}{l}\text { Multiple trials show } \downarrow \text { death or MI with UFH/LMWH in NSTE-ACS[36-42] } \\
\text { SYNERGY (25.5\% age } \geq 75) \text { RCT NSTE-ACS enoxaparin vs. UFH } \\
\text { High risk patients who received invasive management } \\
\leftrightarrow \text { enoxaparin vs. UFH for death or MI at } 30 \text { days } \\
\uparrow \text { TIMI major bleeding[99] } \\
\text { SYNERGY Subgroup analysis age } \geq 75 \\
\leftrightarrow \text { death or MI between UFH and LMWH groups } \\
\text { Higher, non significant increase in bleeding and transfusion rates in elderly enoxaparin group[46] } \\
\text { OASIS-5 RCT NSTE-ACS (Average age } 66.6(+/-10.8-11) \text { fondaparinux vs. enoxaparin } \\
\text { Bleeding risk ( } 217 \text { events }(2.2 \%) \text { vs. } 412 \text { events }(4.1 \%) ; \text { HR, } 0.52 ; \mathrm{P}<0.001) \text { but similar efficacy of } \\
\text { fondaparinux vs. enoxaparin[47] }\end{array}$ & $\begin{array}{l}\text { Special attention must be } \\
\text { given to proper dosing of } \\
\text { antithrombotics in elderly } \\
\text { and renal failure patients.- } \\
\text { ESC[95] } \\
\text { Thrombolysis: } \\
\text { enoxaparin omit iv bolus; } \\
\text { start with first sc dose of } 0.75 \\
\text { mg/kg with a maximum of } 75 \\
\text { mg for the first two sc doses.- } \\
\text { ESC[95] }\end{array}$ \\
\hline 意 & $\begin{array}{l}\text { PROVE IT RCT } 30 \% \text { of cohort } \geq 65 \text { years. High dose atorvastatin vs. pravastatin in ACS } \\
26.3 \% \text { vs. } 22.4 \% \text { ( } \downarrow 16 \% \text { reduction in } \mathrm{HR} \mathrm{P}=0.005 ; 95 \% \mathrm{CI}, 5-26 \% \text { ) reached primary endpoint of } \\
\text { composite death, MI, CVA, late revascularization or readmission for unstable angina } \\
\text { Findings extended to elderly subgroup[51] } \\
\text { Most studies show mortality benefit (many not based on ACS patients) }[52-54] \\
\text { Most evidence for ACS patients extrapolated from studies in younger age groups } \\
\text { In the very elderly there is less evidence and one paper showed a possible association with harm in } \\
\text { patients } \geq 80 \text { years without } C V \text { disease[ } 55]\end{array}$ & $\begin{array}{l}\text { Consider use of lower } \\
\text { intensity statin therapy in } \\
\text { patients at increased risk of } \\
\text { side effects e.g. the elderly- } \\
\text { ESC[95] }\end{array}$ \\
\hline
\end{tabular}


Table 1 continued

\begin{tabular}{|c|c|c|}
\hline & Current Evidence, Risks and Benefits & Guideline \\
\hline 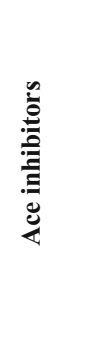 & $\begin{array}{l}\text { GISSI } 3 \text { RCT }(27 \% \text { aged } \geq 70) \text { post MI. lisinopril vs. open control } \\
\downarrow 30.6 \% \text { vs. } 33.8 \% \text { (OR, } 0.86 ; 95 \% \text { CI } 0.77-0.97, \mathrm{P}=0.01) \text { combined death, heart failure and left } \\
\text { ventricular systolic function at } 6 \text { months }[57] \\
\text { SAVE/ AIRE reduced long term mortality in } \geq 65 \text { post MI with reduced left ventricular function[58- } \\
59] \\
\text { Krumholz et al. retrospective observational, ace-i post-MI } n=14,129 \geq 65 \text { years }(29 \% \geq 80 \text { years) } \\
\downarrow 1 \text { year mortality, adjusted risk ratio } 0.85(95 \% \text { CI, } 0.77-0.93, \mathrm{P}=0.001) \\
\text { Benefit also significant within the }>80 \text { year old subgroup[60] }\end{array}$ & \multirow{4}{*}{$\begin{array}{l}\text { Pharmacotherapy in older } \\
\text { patients should be } \\
\text { individualized and dose } \\
\text { adjusted by weight and/or } \\
\text { creatinine clearance to reduce } \\
\text { adverse events caused by } \\
\text { age-related changes in } \\
\text { pharmacokinetics/dynamics, } \\
\text { volume of distribution, co } \\
\text { morbidities, drug } \\
\text { interactions, and increased } \\
\text { drug sensitivity.- } \\
\text { ACCF/AHA[50] }\end{array}$} \\
\hline$\frac{\tilde{c}}{\varkappa}$ & $\begin{array}{l}\text { OPTIMAAL } R C T \text {, high risk post acute MI losartan vs. captopril } \\
\text { All cause mortality } \downarrow \text { in ace-i group (non significant) and fewer discontinuations in ARB group[62] } \\
\text { UMPIRE observational, NSTE-ACS aged } \geq 65 \text { years ARB vs. ace-i } \\
\leftrightarrow \text { rate of hospitalization for ACS, adjusted RR } 0.89,95 \% \text { CI } 0.76-1.04[100]\end{array}$ & \\
\hline 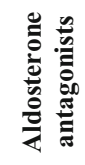 & $\begin{array}{l}\text { EPHESUS RCT Post MI average age } 64 \text { years }(+/-12) \\
\text { Benefit did not extend to elderly subgroup }(\mathrm{n}=\text { ?) risk of hyperkalemia[61, 64] }\end{array}$ & \\
\hline 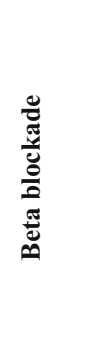 & $\begin{array}{l}\text { Soumerai et al. Retrospective observational }>65 \text { year olds } 3737 / 5332 \text { eligible for beta blockade } \\
43 \% \downarrow \text { mortality RR, } 0.57 ; 95 \% \text { CI, } 0.47-0.69 \\
22 \% \downarrow \text { hospitalization RR, } 0.78 ; 95 \% \text { CI, } 0.67-0.90[65] \\
\text { Krumholz et al. Retrospective observational } \geq 65 \text { years eligible for beta blockade } \\
\downarrow \text { inpatient mortality with beta blockade odds ratio, } 0.81 \text { (95\% CI, } 0.75 \text { to } 0.87)[66] \\
\text { Park et al. Retrospective observational } 60-89 \text { years old receiving oral metoprolol post MI } \\
\text { Age adjusted mortality reduction } 76 \% \text { RR,0.24; } \mathrm{P}<0.001,95 \% \text { CI } 0.11-0.54[67] \\
\text { COMMIT early initiation } \uparrow \text { risk of cardiogenic shock[69] }\end{array}$ & \\
\hline 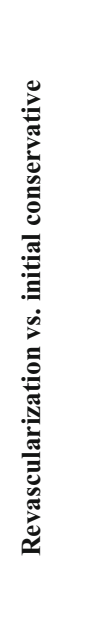 & $\begin{array}{l}\text { FRISC II RCT NSTE-ACS Initial conservative(I.C) vs. invasive strategy excluded }>75 \text { year olds } \\
\text { Aged } 65-75 \text { reduction in composite death and MI with an I.C. strategy compared to age }<65[76] \\
\text { TACTICS TIMI } 18 \text { RCT Initial conservative vs. early invasive (E.I.)(angiography }=+/ \text { at } 4-48 \text { hours) } \\
\text { Significant } \downarrow \text { death or MI with E.I. } \\
\geq 65 \text { years } 8.8 \% \text { vs. } 13.6 \% ; \mathrm{P}=0.018 \\
\geq 75 \text { years } 10.8 \% \text { vs. } 21.6 \% ; \mathrm{P}=0.06 \uparrow \text { bleeding } 16.6 \% \text { vs. } 6.5 \% \mathrm{P}=0.09[78] \\
\text { Damman et al. Meta-analyses of FRISC II, ICTUS and RITA-3. NSTE-ACS. } \\
\text { Differing definitions of "routine invasive". Routine invasive strategy significantly reduced } 5 \text { year } \\
\text { MACE in } 65-74 \text { and } \geq 75 \text { but not in those }<65 \text { years. Significantly } \uparrow \text { in hospital bleeding in older } \\
\text { patients[101] } \\
\text { Savonitto et al. RCT } n=313 \geq 75 \text { years. NSTE-ACS Initial conservative vs. early aggressive }(<72 \\
\text { hours) } \\
\text { Non significant primary endpoint occurred in } 27.9 \% \text { early aggressive vs. } 34.6 \% \text { initial conservative } \\
\text { (for death, MI, disabling stroke, repeat hospital stay for CV cause or severe bleeding within } 1 \text { year) } \\
\text { (HR, } 0.80 ; 95 \% \text { CI, } 0.53-1.19, \mathrm{P}=0.26 \text { ) } \\
\text { However elderly patients with a troponin rise had a } 57 \% \downarrow \text { in primary endpoint (P for interaction= } \\
0.0375 \text { )[79] }\end{array}$ & $\begin{array}{l}\text { Management decisions for } \\
\text { older patients with NSTE- } \\
\text { ACS should be patient } \\
\text { centered, and consider } \\
\text { patient preferences/goals, co } \\
\text { morbidities, functional and } \\
\text { cognitive status, and life } \\
\text { expectancy.-AHA/ACC[9] }\end{array}$ \\
\hline
\end{tabular}


Table 1 continued

\begin{tabular}{|c|c|c|}
\hline & Current Evidence, Risks and Benefits & Guideline \\
\hline 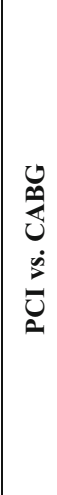 & 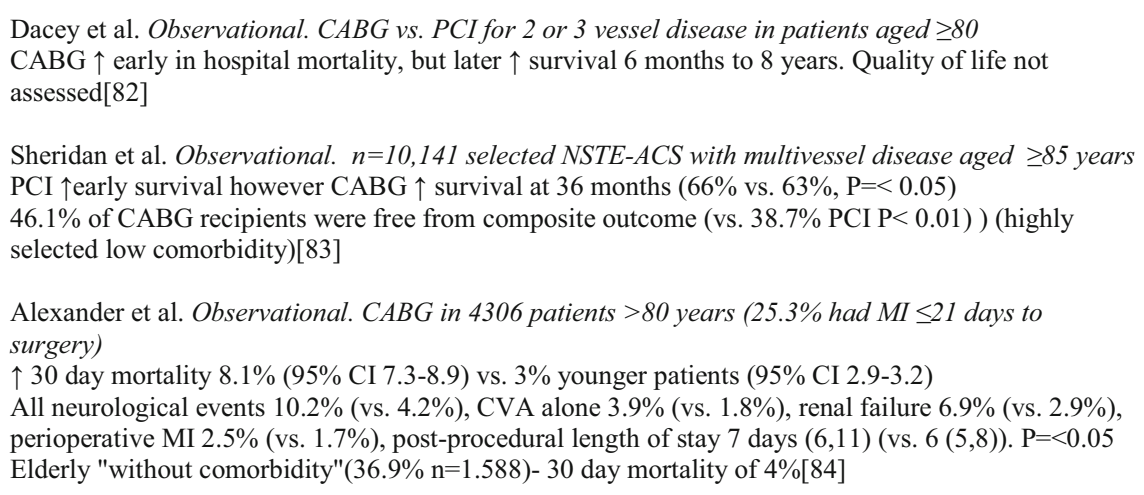 & $\begin{array}{l}\text { It is reasonable to choose } \\
\text { CABG over PCI in older } \\
\text { patients with NSTE-ACS } \\
\text { who are appropriate } \\
\text { candidates, particularly those } \\
\text { with diabetes mellitus or } \\
\text { complex 3-vessel CAD (e.g. } \\
\text { SYNTAX score }>22 \text { ), with or } \\
\text { without involvement of the } \\
\text { proximal LAD artery, to } \\
\text { reduce cardiovascular disease } \\
\text { events and readmission and } \\
\text { to improve survival- } \\
\text { AHA/ACC[9] }\end{array}$ \\
\hline 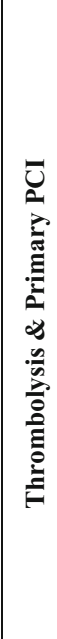 & $\begin{array}{l}\text { GISSI } R C T \text { subgroup selected patients aged }>75 \text { years: } \\
\text { trend toward } \downarrow \text { mortality with streptokinase versus control } \\
28.9 \% \text { vs. } 33.1 \% \text { at } 21 \text { days } \\
43.1 \% \text { vs. } 46.1 \% \text { at } 1 \text { year[ } 89] \\
\\
\text { de Boer et al. } R C T>75 \text { years old, } n=75 \text {, angioplasty vs. lysis } \\
\text { Primary end point (composite of death, reinfarction or stroke) } \\
30 \text { days } 9 \% \text { vs. } 29 \% \text { lysis group ( } \mathrm{P}=0.01, \mathrm{RR}: 4.3,95 \% \text { CI: } 1.2-20.0) \\
1 \text { year corresponding figures } 6(13 \%) \text { and } 18(44 \%) \text {, respectively (P=0.001, RR: } 5.2,95 \% \text { CI: } 1.7 \text { - } \\
18.1)[96] \\
\text { TRIANA } R C T n=266 \text { primary } P C I \text { vs. thrombolysis an age } \geq 75 \\
\text { Discontinued early due to slow recruitment. } \\
\text { Primary endpoint (composite all cause mortality, reinfarction, disabling CVA at } 30 \text { days) primary PCI } \\
18.9 \% \text { vs. } 25.4 \% \text { in the lysis arm OR, } 0.69 ; 95 \% \text { CI } 0.38-1.23 ; \mathrm{P}=0.21 \\
\downarrow \text { Recurrent ischemia in primary PCI-treated patients }(0.8 \text { vs. } 9.7 \%, \mathrm{P}<0.001) \\
\text { No differences were found in major bleeds[ }[97] \\
\text { Pooled analysis with } 2 \text { prior trials showed an advantage of primary PCI over lysis in reducing death, } \\
\text { re-infarction, or CVA at } 30 \text { days (OR, } 0.64 ; 95 \% \text { CI } 0.45-0.91)[97]\end{array}$ & \\
\hline
\end{tabular}

$A C S$ acute coronary syndrome, $A C C F / A H A$ American College of Cardiology Foundation/American Heart Foundation, $A H A / A C C$ American Heart Association/American Heart Association, $A R$ absolute risk, $A R B$ angiotensin receptor blocker, $C A B G$ coronary artery bypass graft, $C A D$ coronary artery disease, $C I$ confidence interval, $C V$ cardiovascular, $C V A$ cerebrovascular accident, ESC European Cardiac Society, GDMT guideline-directed medical therapy, $H R$ hazard ratio, iv intravenous, $\mathrm{kg}$ kilograms, $m g$ milligrams, LAD left anterior descending, $M I$ myocardial infarction, NSTE-ACS non ST elevation acute coronary syndrome, $O R$ odds ratio, $P p$ value, $P C I$ percutaneous coronary intervention, $R C T$ randomized controlled trial, $R R$ relative risk, sc subcutaneous, STEMI ST elevation myocardial infarction, SYNTAX Synergy between Percutaneous Coronary Intervention with TAXUS and Cardiac Surgery, TIA transient ischemic attack, TIMI thrombolysis in myocardial infarction, $U F H$ unfractionated heparin

recurrent myocardial infarction in the first 30 days after randomization) with enoxaparin compared to unfractionated heparin in all subgroups [94]. The enoxaparin group experienced a higher rate of TIMI major bleeding (including intracranial hemorrhage) at 30 days [94]. This reduced dosing regimen is suggested by current ESC guidelines for patients 
over 75 years old as an adjunct to thrombolysis (i.e., patients selected to be appropriate for lysis and who do not have access to primary PCI within $120 \mathrm{~min}$ of first medical contact) [95]. Current American guidelines state that LMWH should not be used as an alternative to unfractionated heparin in patients over the age of 75 who are receiving fibrinolytics [50].

In Europe, thrombolysis has largely been superseded by primary PCI, and multiple small trials have reduced death, reinfarction, and CVA in elderly patients with PCI vs. thrombolysis, consistent with results in younger patients [88, $91,96,97]$. However, despite the availability of primary PCI, elderly patients with STEMI still experience inequalities in care. The CRUSADE initiative reported that there was no attempt to administer reperfusion therapy in $7.2 \%$ of non-contraindicated STEMI patients, with reasons cited including older age, female gender, and comorbidity, and such patients had greater in-hospital mortality [98]. AHA/ ACC guidelines state that age alone should not disqualify a patient from early revascularization. Instead, we should use individual judgment based on comorbidities, functional status, and patient directives [47].

\section{CONCLUSION}

Whilst newer guidelines acknowledge the rapidly increasing elderly population and its ensuing challenges, it is difficult to create an all-encompassing guideline for such a varied population. Diversity in patient characteristics such as frailty, baseline function, comorbidity, and cognition presents a unique challenge. Biological and chronological ages can differ, and it is therefore the physician's duty not to base treatment choices on age alone. Furthermore, the term "elderly" can cover a period of several decades from 65 years old ona period during which there are marked changes in patient physiology.

Underrepresentation in trials has led to a comparative lack of evidence and, although there are increasing efforts to complete phase 4 trials in the elderly population, we are still left with questions about how we should best treat our elderly patients.

American and European guidelines emphasize the importance of considering the individual patient. Efforts to comply with current guidance developed from trials in younger cohorts could lead to maleficence such as bleeding or renal failure, so many physicians omit therapy. Conversely, omission of treatment could likewise harm a patient who may otherwise benefit.

Efforts must be made to improve vigilance and recognition of atypical presentation in elderly patients. It is important to collect accurate information promptly which can then be used to judge each patient's suitability for treatment, and not to bias our decisions based on age alone. Furthermore, it is imperative that we facilitate an informed decision-making process for the patient, adapting the information we convey to the individual.

Guideline-directed medical therapy should be considered in the context of the individual patient, with clear reasons for proceeding with (benefits exceed risks) or omitting (risks exceed benefits) treatment. The final decision should be based on current evidence, physician judgment, and patient preference.

\section{ACKNOWLEDGMENTS}

No funding or sponsorship was received for this study or publication of this article. All named 
authors meet the International Committee of Medical Journal Editors (ICMJE) criteria for authorship for this manuscript, take responsibility for the integrity of the work as a whole, and have given final approval for the version to be published.

Conflict of interest. Claire McCune and Peter McKavanagh declare they have no conflicts of interest. Ian Menown has received grants to institution, honoraria, and/or conference sponsorship from Boston Scientific, Sanofi Aventis, Biosensors, Meril Life, OrbusNeich, Menarini, AstraZeneca, Bayer, Boehringer Ingelheim, Daiichi Sankyo, Lilly, Bristol-Myers Squibb, and Pfizer.

Compliance with ethics guidelines. This article is based on previously conducted studies and does not involve any new studies of human or animal subjects performed by any of the authors.

Open Access. This article is distributed under the terms of the Creative Commons Attribution-NonCommercial 4.0 International License (http://creativecommons.org/licenses/ by-nc/4.0/), which permits any noncommercial use, distribution, and reproduction in any medium, provided you give appropriate credit to the original author(s) and the source, provide a link to the Creative Commons license, and indicate if changes were made.

\section{REFERENCES}

1. Wienbergen H, Gitt AK, Schiele R, Juenger C, Heer $\mathrm{T}$, Vogel C, et al. Different treatments and outcomes of consecutive patients with non-ST-elevation myocardial infarction depending on initial electrocardiographic changes (results of the Acute Coronary Syndromes [ACOS] Registry). Am J Cardiol. 2004;93(12):1543-6.
2. Rana O, Moran R, O'Kane P, Boyd S, Swallo R, Talwar S, et al. Percutaneous coronary intervention in the very elderly $(>/=85$ years $)$ t trends and outcomes. Br J Cardiol. 2013;20(1):27-31.

3. Zaman MJ, Stirling S, Shepstone L, Ryding A, Flather $\mathrm{M}$, Bachmann $\mathrm{M}$, et al. The association between older age and receipt of care and outcomes in patients with acute coronary syndromes: a cohort study of the Myocardial Ischaemia National Audit Project (MINAP). Eur Heart J. 2014;35(23).

4. Alexander KP, Newby LK, Cannon CP, Armstrong PW, Gibler WB, Rich MW, et al. Acute coronary care in the elderly, part I: non-ST-segment-elevation acute coronary syndromes: a scientific statement for healthcare professionals from the American Heart Association Council on Clinical Cardiology: in collaboration with the Society of Geriatric Cardiology. Circulation. 2007;115(19):2549-69.

5. Mehta RH, Rathore SS, Radford MJ, Wang Y, Wang Y, Krumholz HM. Acute myocardial infarction in the elderly: differences by age. J Am Coll Cardiol. 2001;38(3):736-41.

6. De Luca L, Olivari Z, Bolognese L, Lucci D, Gonzini L, Di Chiara A, et al. A decade of changes in clinical characteristics and management of elderly patients with non-ST elevation myocardial infarction admitted in Italian cardiac care units. Open Heart. 2014;1(1).

7. Simms AD, Batin PD, Kurian J, Durham N, Gale CP. Acute coronary syndromes: an old age problem. J Geriatr Cardiol JGC. 2012;9(2):192-6.

8. Rawshani A, Larsson A, Gelang C, Lindqvist J, Gellerstedt M, Bang A, et al. Characteristics and outcome among patients who dial for the EMS due to chest pain. Int J Cardiol. 2014;176(3):859-65.

9. Amsterdam EA, Wenger NK, Brindis RG, Casey DE, Ganiats TG, Holmes DR, et al. 2014 AHA/ACC Guideline for the Management of Patients With Non-ST-Elevation Acute Coronary Syndromes: a report of the American College of Cardiology/ American Heart Association Task Force on Practice Guidelines. Circulation. 2014;130(25):e344-426.

10. Hamm CW, Bassand J-P, Agewall S, Bax J, Boersma $\mathrm{E}$, Bueno $\mathrm{H}$, et al. ESC Guidelines for the management of acute coronary syndromes in patients presenting without persistent ST-segment elevation. Eur Heart J. 2011;32(23):2999-3054.

11. Alexander KP, Roe MT, Chen AY, Lytle BL, Pollack CV Jr, Foody JM, et al. Evolution in cardiovascular care for elderly patients with non-ST-segment elevation acute coronary syndromes: results from the CRUSADE National Quality Improvement Initiative. J Am Coll Cardiol. 2005;46(8):1479-87. 
12. Brieger D, Eagle KA, Goodman SG, Steg PG, Budaj A, White $\mathrm{K}$, et al. Acute coronary syndromes without chest pain, an underdiagnosed and undertreated high-risk group: insights from the Global Registry of Acute Coronary Events. Chest. 2004;126(2):461-9.

13. Gale CP, Cattle BA, Woolston A, Baxter PD, West $\mathrm{TH}$, Simms AD, et al. Resolving inequalities in care? Reduced mortality in the elderly after acute coronary syndromes. The Myocardial Ischaemia National Audit Project 2003-2010. Eur Heart J. 2012;33(5):630-9.

14. Krumholz HM, Radford MJ, Ellerbeck EF, Hennen J, Meehan TP, Petrillo $M$, et al. Aspirin in the treatment of acute myocardial infarction in elderly Medicare beneficiaries. Patterns of use and outcomes. Circulation. 1995;92(10):2841-7.

15. Patrono C, García Rodríguez LA, Landolfi R, Baigent C. Low-dose aspirin for the prevention of atherothrombosis. $\mathrm{N}$ Engl J Med. 2005;353(22):2373-83.

16. Antithrombotic Trialists' Collaboration. Collaborative meta-analysis of randomised trials of antiplatelet therapy for prevention of death, myocardial infarction, and stroke in high risk patients. BMJ. 2002;324(7329):71-86.

17. Parikh S, Sharkey K, Workman B. Cardiovascular risk reduction in the extreme elderly. J Pharm Pract Res. 2013;43(1):62-8.

18. Moscucci M, Fox KAA, Cannon CP, Klein W, López-Sendón J, Montalescot G, et al. Predictors of major bleeding in acute coronary syndromes: the Global Registry of Acute Coronary Events (GRACE). Eur Heart J. 2003;24(20):1815-23.

19. Roe M, Duke University. Aspirin Dosing: A Patient-Centric Trial Assessing Benefits and Long-term Effectiveness (ADAPTABLE). Available from: http://www.pcori.org/research-results/2015/ aspirin-dosing-patient-centric-trial-assessing-benefitsand-long-term. Accessed 24 May 2015.

20. Chen ZM, et al. Addition of clopidogrel to aspirin in 45852 patients with acute myocardial infarction: randomised placebo-controlled trial. The Lancet. 366(9497):1607-21.

21. Yusuf S, Zhao F, Mehta SR, Chrolavicius S, Tognoni $\mathrm{G}$, et al. Clopidogrel in Unstable Angina to Prevent Recurrent Events Trial Investigators. Effects of clopidogrel in addition to aspirin in patients with acute coronary syndromes without ST-segment elevation. N Engl J Med. 2001;345(7):494-502.

22. Mehta SR, Yusuf S, Peters RJ, Bertrand ME, Lewis BS, Natarajan MK, et al. Effects of pretreatment with clopidogrel and aspirin followed by long-term therapy in patients undergoing percutaneous coronary intervention: the PCI-CURE study. Lancet. 2001;358(9281):527-33.

23. Budaj A, Yusuf S, Mehta SR, Fox KAA, Tognoni G, Zhao F, et al. Benefit of clopidogrel in patients with acute coronary syndromes without ST-segment elevation in various risk groups. Circulation. 2002;106(13):1622-6.

24. Aronow WS. Use of antiplatelet drugs in secondary prevention in older persons with atherothrombotic disease. J Gerontol Ser A Biol Sci Med Sci. 2007;62(5):518-24.

25. Wallentin L, Becker RC, Budaj A, Cannon CP, Emanuelsson $\mathrm{H}$, Held $\mathrm{C}$, et al. Ticagrelor versus clopidogrel in patients with acute coronary syndromes. N Engl J Med. 2009;361(11):1045-57.

26. Becker RC, Bassand JP, Budaj A, Wojdyla DM, James $\mathrm{SK}$, Cornel JH, et al. Bleeding complications with the P2Y12 receptor antagonists clopidogrel and ticagrelor in the PLATelet inhibition and patient Outcomes (PLATO) trial. Eur Heart J. 2011;32(23):2933-44.

27. Steg PG, James S, Harrington RA, Ardissino D, Becker RC, Cannon CP, et al. Ticagrelor versus clopidogrel in patients with ST-elevation acute coronary syndromes intended for reperfusion with primary percutaneous coronary intervention: a Platelet Inhibition and Patient Outcomes (PLATO) trial subgroup analysis. Circulation. 2010;122(21):2131-41.

28. Lindholm D, Varenhorst C, Cannon CP, Harrington RA, Himmelmann A, Maya J, et al. Ticagrelor vs. clopidogrel in patients with non-ST-elevation acute coronary syndrome with or without revascularization: results from the PLATO trial. Eur Heart J. 2014;35(31):2083-93.

29. Husted S, James S, Becker RC, Horrow J, Katus H, Storey RF, et al. Ticagrelor versus clopidogrel in elderly patients with acute coronary syndromes: a substudy from the prospective randomized PLATelet inhibition and patient Outcomes (PLATO) trial. Circu Cardiovasc Qual Outcomes. 2012;5(5):680-8.

30. Bonaca MP, Bhatt DL, Cohen M, Steg PG, Storey RF, Jensen EC, et al. Long-term use of ticagrelor in patients with prior myocardial infarction. N Engl J Med. 2015;372(19):1791-800.

31. Wiviott SD, Braunwald E, McCabe $\mathrm{CH}$, Montalescot G, Ruzyllo W, Gottlieb S, et al. Prasugrel versus clopidogrel in patients with acute coronary syndromes. $\mathrm{N}$ Engl J Med. 2007;357(20):2001-15. 
32. Wiviott SD, Antman EM, Braunwald E. Prasugrel. Circulation. 2010;122(4):394-403.

33. Hochholzer W, Wiviott SD, Antman EM, Contant CF, Guo J, Giugliano RP, et al. Predictors of bleeding and time dependence of association of bleeding with mortality: insights from the Trial to Assess Improvement in Therapeutic Outcomes by Optimizing Platelet Inhibition With Prasugrel-Thrombolysis in Myocardial Infarction 38 (TRITON-TIMI 38). Circulation. 2011;123(23):2681-9.

34. Daiichi Sankyo, Inc., Lilly USA. Effient SPC 2015. Available from: https://www.effient.com/. Accessed 24 May 2015

35. Roe MT, Goodman SG, Ohman EM, Stevens SR, Hochman JS, Gottlieb S, et al. Elderly patients with acute coronary syndromes managed without revascularization: insights into the safety of long-term dual antiplatelet therapy with reduced-dose prasugrel versus standard-dose clopidogrel. Circulation. 2013;128(8):823-33.

36. Theroux P, Ouimet H, McCans J, Latour JG, Joly P, Levy G, et al. Aspirin, heparin, or both to treat acute unstable angina. $\mathrm{N}$ Engl J Med. 1988;319(17):1105-11.

37. Cohen M, Adams PC, Hawkins L, Bach M, Fuster V. Usefulness of antithrombotic therapy in resting angina pectoris or non-Q-wave myocardial infarction in preventing death and myocardial infarction (a pilot study from the Antithrombotic Therapy in Acute Coronary Syndromes Study Group). Am J Cardiol. 1990;66(19):1287-92.

38. The RISC Group. Risk of myocardial infarction and death during treatment with low dose aspirin and intravenous heparin in men with unstable coronary artery disease. Lancet. 1990;336(8719):827-30.

39. Cohen M, Adams PC, Parry G, Xiong J, Chamberlain D, Wieczorek I, et al. Combination antithrombotic therapy in unstable rest angina and non-Q-wave infarction in nonprior aspirin users. Primary end points analysis from the ATACS trial. Antithrombotic Therapy in Acute Coronary Syndromes Research Group. Circulation. 1994;89(1):81-8.

40. Holdright D, Patel D, Cunningham D, Thomas R, Hubbard W, Hendry G, et al. Comparison of the effect of heparin and aspirin versus aspirin alone on transient myocardial ischemia and in-hospital prognosis in patients with unstable angina. J Am Coll Cardiol. 1994;24(1):39-45.

41. Gurfinkel EP, Manos EJ, Mejail RI, Cerda MA, Duronto EA, Garcia CN, et al. Low molecular weight heparin versus regular heparin or aspirin in the treatment of unstable angina and silent ischemia. J Am Coll Cardiol. 1995;26(2):313-8.

42. Fragmin during Instability in Coronary Artery Disease (FRISC) study group. Low-molecular-weight heparin during instability in coronary artery disease. Lancet. 1996;347(9001):561-8.

43. Boersma E, Van de Werf F, Zjilstra F. The ESC textbook of cardiovascular medicine. 2nd ed. Oxford: Blackwell Publishing; 2005.

44. Campbell NR, Hull RD, Brant R, Hogan DB, Pineo GF, Raskob GE. Aging and heparin-related bleeding. Arch Intern Med. 1996;156(8):857-60.

45. Menown I. New anticoagulant strategies in ST-elevation myocardial infarction treated with fibrinolytic therapy. Br J Cardiol. 2008;15(2):87-94.

46. Lopes RD, Alexander KP, Marcucci G, White HD, Spinler S, Col J, et al. Outcomes in elderly patients with acute coronary syndromes randomized to enoxaparin vs. unfractionated heparin: results from the SYNERGY trial. Eur Heart J. 2008;29(15):1827-33.

47. Fifth Organization to Assess Strategies in Acute Ischemic Syndromes I, Yusuf S, Mehta SR, Chrolavicius S, Afzal R, Pogue J, et al. Comparison of fondaparinux and enoxaparin in acute coronary syndromes. N Engl J Med. 2006;354:1464-76.

48. Kannel WB, Benjamin EJ. Final draft status of the epidemiology of atrial fibrillation. Med Clin North Am. 2008;92(1):17-ix.

49. Hart RG, Tonarelli SB, Pearce LA. Avoiding central nervous system bleeding during antithrombotic therapy: recent data and ideas. Stroke. 2005;36(7):1588-93.

50. O'Gara PT, Kushner FG, Ascheim DD, Casey DE, Chung MK, de Lemos JA, et al. 2013 ACCF/AHA Guideline for the Management of ST-Elevation Myocardial Infarction: a report of the American College of Cardiology Foundation/American Heart Association Task Force on Practice Guidelines. J Am Coll Cardiol. 2013;61(4):e78-140.

51. Cannon CP, Braunwald E, McCabe CH, Rader DJ, Rouleau JL, Belder $\mathrm{R}$, et al. Intensive versus moderate lipid lowering with statins after acute coronary syndromes. $\mathrm{N}$ Engl J Med. 2004;350(15):1495-504.

52. Shepherd J, Blauw GJ, Murphy MB, Bollen EL, Buckley BM, Cobbe SM, et al. Pravastatin in elderly individuals at risk of vascular disease (PROSPER): a randomised controlled trial. Lancet. 2002;360(9346):1623-30. 
53. Lewis SJ, Moye LA, Sacks FM, Johnstone DE, Timmis G, Mitchell J, et al. Effect of pravastatin on cardiovascular events in older patients with myocardial infarction and cholesterol levels in the average range. Results of the Cholesterol and Recurrent Events (CARE) trial. Ann Intern Med. 1998;129(9):681-9.

54. The Long-Term Intervention with Pravastatin in Ischaemic Disease (LIPID) Study Group. Prevention of cardiovascular events and death with pravastatin in patients with coronary heart disease and a broad range of initial cholesterol levels. N Engl J Med. 1998;339(19):1349-57.

55. Petersen LK, Christensen K, Kragstrup J. Lipid-lowering treatment to the end? A review of observational studies and RCTs on cholesterol and mortality in 80+-year olds. Age Ageing. 2010;39(6):674-80.

56. National Institute for Health and Care Excellence. NICE guidelines: Lipid modification: cardiovascular risk assessment and the modification of blood lipids for the primary and secondary prevention of cardiovascular disease. Available from: http:// www.nice.org.uk/guidance/cg181. Accessed 24 May 2015

57. Gruppo Italiano per lo Studio della Sopravvivenza nell'Infarto Miocardico. Six-month effects of early treatment with lisinopril and transdermal glyceryl trinitrate singly and together withdrawn six weeks after acute myocardial infarction: the GISSI-3 trial. J Am Coll Cardiol. 1996;27(2):337-44.

58. Pfeffer MA, Braunwald E, Moyé LA, Basta L, Brown EJ, Cuddy TE, et al. Effect of captopril on mortality and morbidity in patients with left ventricular dysfunction after myocardial infarction. N Engl J Med. 1992;327(10):669-77.

59. The Acute Infarction Ramipril Efficacy (AIRE) Study Investigators. Effect of ramipril on mortality and morbidity of survivors of acute myocardial infarction with clinical evidence of heart failure. Lancet. 1993;342(8875):821-8.

60. Krumholz HM, Chen YT, Wang Y, Radford MJ. Aspirin and angiotensin-converting enzyme inhibitors among elderly survivors of hospitalization for an acute myocardial infarction. Arch Intern Med. 2001;161(4):538-44.

61. Alexander KP, Newby LK, Armstrong PW, Cannon $\mathrm{CP}$, Gibler WB, Rich MW, et al. Acute coronary care in the elderly, part II: ST-segment-elevation myocardial infarction: a scientific statement for healthcare professionals from the American Heart Association Council on Clinical Cardiology: in collaboration with the Society of Geriatric Cardiology. Circulation. 2007;115(19):2570-89.
62. Dickstein K, Kjekshus J. Effects of losartan and captopril on mortality and morbidity in high-risk patients after acute myocardial infarction: the OPTIMAAL randomised trial. Optimal Trial in Myocardial Infarction with Angiotensin II Antagonist Losartan. Lancet. 2002;360(9335):752-60.

63. White HD, Aylward PE, Huang Z, Dalby AJ, Weaver WD, Barvik S, et al. Mortality and morbidity remain high despite captopril and/or valsartan therapy in elderly patients with left ventricular systolic dysfunction, heart failure, or both after acute myocardial infarction: results from the Valsartan in Acute Myocardial Infarction Trial (VALIANT). Circulation. 2005;112(22):3391-9.

64. Pitt B, Remme W, Zannad F, Neaton J, Martinez F, Roniker B, et al. Eplerenone, a selective aldosterone blocker, in patients with left ventricular dysfunction after myocardial infarction. N Engl J Med. 2003;348(14):1309-21.

65. Soumerai SB, McLaughlin TJ, Spiegelman D, Hertzmark E, Thibault G, Goldman L. Adverse outcomes of underuse of beta-blockers in elderly survivors of acute myocardial infarction. JAMA. 1997;277(2):115-21.

66. Krumholz HM, Radford MJ, Wang Y, Chen J, Marciniak TA. Early beta-blocker therapy for acute myocardial infarction in elderly patients. Ann Intern Med. 1999;131(9):648-54.

67. Park KC, Forman DE, Wei JY. Utility of beta-blockade treatment for older postinfarction patients. J Am Geriatr Soc. 1995;43(7):751-5.

68. Pfisterer M, Cox JL, Granger CB, Brener SJ, Naylor $\mathrm{CD}$, Califf RM, et al. Atenolol use and clinical outcomes after thrombolysis for acute myocardial infarction: the GUSTO-I experience. Global Utilization of Streptokinase and TPA (alteplase) for Occluded Coronary Arteries. J Am Coll Cardiol. 1998;32(3):634-40.

69. Chen ZM, Pan HC, Chen YP, Peto R, Collins R, Jiang LX, et al. Early intravenous then oral metoprolol in 45,852 patients with acute myocardial infarction: randomised placebo-controlled trial. Lancet. 2005;366(9497):1622-32.

70. Saunderson CED, Brogan RA, Simms AD, Sutton G, Batin PD, Gale CP. Acute coronary syndrome management in older adults: guidelines, temporal changes and challenges. Age Ageing. 2014;43(4):450-5.

71. Suaya JA, Shepard DS, Normand SL, Ades PA, Prottas J, Stason WB. Use of cardiac rehabilitation by Medicare beneficiaries after myocardial infarction or coronary bypass surgery. Circulation. 2007;116(15):1653-62. 
72. Menezes AR, Lavie CJ, Milani RV, Arena RA, Church TS. Cardiac rehabilitation and exercise therapy in the elderly: should we invest in the aged? J Geriatr Cardiol. 2012;9(1):68-75.

73. Wenger NK, Rosenson RS, Braun LT. Cardiac rehabilitation: evidence of benefit in patients with coronary heart disease. Available from: http:// www.uptodate.com/contents/cardiac-rehabilitationevidence-of-benefit-in-patients-with-coronary-heartdisease

74. TIME Investigators. Trial of invasive versus medical therapy in elderly patients with chronic symptomatic coronary-artery disease (TIME): a randomised trial. Lancet. 2001;358(9286):951-7.

75. Graham MM, Ghali WA, Faris PD, Galbraith PD, Norris CM, Knudtson ML, et al. Survival after coronary revascularization in the elderly. Circulation. 2002;105(20):2378-84.

76. Lagerqvist B, Husted S, Kontny F, Ståhle E, Swahn E, Wallentin L. 5-year outcomes in the FRISC-II randomised trial of an invasive versus a non-invasive strategy in non-ST-elevation acute coronary syndrome: a follow-up study. Lancet. 2006;368(9540):998-1004.

77. Cannon CP, Weintraub WS, Demopoulos LA, Vicari R, Frey MJ, Lakkis N, et al. Comparison of early invasive and conservative strategies in patients with unstable coronary syndromes treated with the glycoprotein IIb/IIIa inhibitor tirofiban. N Engl J Med. 2001;344(25):1879-87.

78. Bach RG, Cannon CP, Weintraub WS, DiBattiste PM, Demopoulos LA, Anderson HV, et al. The effect of routine, early invasive management on outcome for elderly patients with non-ST-segment elevation acute coronary syndromes. Ann Intern Med. 2004;141(3):186-95.

79. Savonitto S, Cavallini C, Petronio AS, Murena E, Antonicelli R, Sacco A, et al. Early aggressive versus initially conservative treatment in elderly patients with non-ST-segment elevation acute coronary syndrome: a randomized controlled trial. JACC. 2012;5(9):906-16.

80. Johnman C, Oldroyd KG, Mackay DF, Slack R, Pell $\mathrm{AC}$, Flapan $\mathrm{AD}$, et al. Percutaneous coronary intervention in the elderly: changes in case-mix and periprocedural outcomes in 31,758 patients treated between 2000 and 2007. Circ Cardiovasc Inter. 2010;3(4):341-5.

81. Weintraub WS, Grau-Sepulveda MV, Weiss JM, O'Brien SM, Peterson ED, Kolm P, et al. Comparative effectiveness of revascularization strategies. N Engl J Med. 2012;366(16):1467-76.
82. Dacey LJ, Likosky DS, Ryan TJ Jr, Robb JF, Quinn RD, DeVries JT, et al. Long-term survival after surgery versus percutaneous intervention in octogenarians with multivessel coronary disease. Ann Thorac Surg. 2007;84(6):1904-11.

83. Sheridan BC, Stearns SC, Rossi JS, D'Arcy LP, Federspiel JJ, Carey TS. Three-year outcomes of multivessel revascularization in very elderly acute coronary syndrome patients. Ann Thorac Surg. 2010;89(6):1889-95.

84. Alexander KP, Anstrom KJ, Muhlbaier LH, Grosswald RD, Smith PK, Jones RH, et al. Outcomes of cardiac surgery in patients $>$ or $=$ 80 years: results from the National Cardiovascular Network. J Am Coll Cardiol. 2000;35(3):731-8.

85. Hlatky MA, Boothroyd DB, Baker L, Kazi DS, Solomon MD, Chang TI, et al. Comparative effectiveness of multivessel coronary bypass surgery and multivessel percutaneous coronary intervention: a cohort study. Ann Intern Med. 2013;158(10):727-34.

86. Bardakci H, Cheema FH, Topkara VK, Dang NC, Martens TP, Mercando ML, et al. Discharge to home rates are significantly lower for octogenarians undergoing coronary artery bypass graft surgery. Ann Thorac Surg. 2007;83(2):483-9.

87. White HD, Van de Werf FJJ. Thrombolysis for acute myocardial infarction. Circulation. 1998;97(16):1632-46.

88. White HD, Barbash GI, Califf RM, Simes RJ, Granger $\mathrm{CB}$, Weaver WD, et al. Age and outcome with contemporary thrombolytic therapy. Results from the GUSTO-I trial. Global Utilization of Streptokinase and TPA for Occluded coronary arteries trial. Circulation. 1996;94(8):1826-33.

89. Gruppo Italiano per lo Studio della Streptochi-nasi nell'Infarto Miocardico (GISSI). Long-term effects of intravenous thrombolysis in acute myocardial infarction: final report of the GISSI study. Lancet. 330(8564):871-4.

90. ISIS-2 (Second International Study of Infarct Survival) Collaborative Group. Randomised trial of intravenous streptokinase, oral aspirin, both, or neither among 17,187 cases of suspected acute myocardial infarction: ISIS-2. Lancet. 1988;2(8607):349-60.

91. Berger AK, Radford MJ, Wang Y, Krumholz HM. Thrombolytic therapy in older patients. J Am Coll Cardiol. 2000;36(2):366-74.

92. Menown I, Patterson R, McMechan S, Hameed S, Adgey A. Thrombolytic therapy in routine practice: 
utilization in females, diabetics and the elderly. J Am Coll Cardiol. 1998;31(5):165C.

93. Wallentin LGP, Armstrong PW, Granger CB, Adgey AA, Arntz HR, Bogaerts K, Danays T, Lindahl B, Makijarvi M, Verheugt F, Van deWerf F. Efficacy and safety of tenecteplase in combination with the low-molecular-weight heparin enoxaparin or unfractionated heparin in the pre-hospital setting: the Assessment of the Safety and Efficacy of a New Thrombolytic Regimen (ASSENT)-3 PLUS randomized trial in acute myocardial infarction. Circulation. 2003;108:135-42.

94. Giraldez RRNJ, Corbalan R, Gurfinkel EP, Juarez U, Lopez-Sendon J, Parkhomenko A, Molhoek P, Mohanavelu S, Morrow DA, Antman EM. Enoxaparin is superior to unfractionated heparin in patients with ST elevation myocardial infarction undergoing fibrinolysis regardless of the choice of lytic: an ExTRACT-TIMI 25 analysis. Eur Heart J. 2007;28:1566-73.

95. Task Force on the Management of ST-Segment Elevation Acute Myocardial Infarction of the European Society of Cardiology (ESC), Steg PG, James SK, Atar D, Badano LP, Blömstrom-Lundqvist C, Borger MA, Di Mario C, Dickstein K, Ducrocq G, Fernandez-Aviles F, Gershlick AH, Giannuzzi P, Halvorsen S, Huber K, Juni P, Kastrati A, Knuuti J, Lenzen MJ, Mahaffey KW, Valgimigli M, van't Hof A, Widimsky P, Zahger D. ESC Guidelines for the management of acute myocardial infarction in patients presenting with ST-segment elevation. Eur Heart J. 2012(33):2569-619.

96. de Boer MJ, Ottervanger JP, van't Hof AW, Hoorntje JC, Suryapranata H, Zijlstra F. Reperfusion therapy in elderly patients with acute myocardial infarction: a randomized comparison of primary angioplasty and thrombolytic therapy. J Am Coll Cardiol. 2002;39(11):1723-8.

97. Bueno H, Betriu A, Heras M, Alonso JJ, Cequier A, García EJ, et al. Primary angioplasty vs. fibrinolysis in very old patients with acute myocardial infarction: tRIANA (TRatamiento del Infarto Agudo de miocardio eN Ancianos) randomized trial and pooled analysis with previous studies. Eur Heart J. 2011;32(1):51-60.

98. Gharacholou SM, Alexander KP, Chen AY, Wang TY, Melloni C, Gibler WB, et al. Implications and reasons for the lack of use of reperfusion therapy in patients with ST-segment elevation myocardial infarction: findings from the CRUSADE initiative. Am Heart J. 2010;159(5):757-63.

99. Ferguson JJ, Califf RM, Antman EM, Cohen M, Grines CL, Goodman S, Kereiakes DJ, Langer A, Mahaffey KW, Nessel CC, Armstrong PW, Avezum A, Aylward P, Becker RC, Biasucci L, Borzak S, Col J, Frey MJ, Fry E, Gulba DC, Guneri S, Gurfinkel E, Harrington R, Hochman JS, Kleiman NS, Leon MB, Lopez-Sendon JL, Pepine CJ, Ruzyllo W, Steinhubl SR, Teirstein PS, Toro-Figueroa L, White $H$, SYNERGY Trial Investigators. Enoxaparin vs unfractionated heparin in high-risk patients with non-ST-segment elevation acute coronary syndromes managed with an intended early invasive strategy: primary results of the synergy randomized trial. JAMA. 2004;292(1):45-54.

100. Verma S, Mamdani MM, Al-Omran M, Melo M, Rouleau JL. Angiotensin receptor blockers vs. angiotensin converting enzyme inhibitors and acute coronary syndrome outcomes in elderly patients: a population-based cohort study (UMPIRE study results). J Am Soc Hypertens. 1(4):286-94.

101. Damman P, Clayton T, Wallentin L, Lagerqvist B, Fox KA, Hirsch A, et al. Effects of age on long-term outcomes after a routine invasive or selective invasive strategy in patients presenting with non-ST segment elevation acute coronary syndromes: a collaborative analysis of individual data from the FRISC II-ICTUS-RITA-3 (FIR) trials. Heart (British Cardiac Society). 2012;98(3):207-13. 